УДК 321.7

DOI https://doi.org/10.51989/NUL.2021.6.18

\title{
ПАРТИСИПАТИВНА ТА ПРЕДСТАВНИЦЬКА ДЕМОКРАТІЯ У МІСЦЕВОМУ САМОВРЯДУВАННI: ПИТАННЯ СПІВВІДНОШЕННЯ
}

\section{Нікітенко Лілія Олександрівна,}

кандидат юридичних наук, доцент, доцент кафедри конституційного, міжнародного і кримінального права Донецького національного університету імені Василя Стуса

\section{Грабар Олександра Сергіївна,}

студентка юридичного факультету

Донецького національного університету імені Василя Стуса

У статті висвітлено співвідношення представницької та партисипативної демократії у місцевому самоврядуванні.

Зазначено, що дослідження різних видів демократії на місцевому рівні актуалізується сьогодні у зв'язку з проведенням реформи децентралізації влади, яка насамперед спрямована на розвиток місцевого самоврядування в Україні.

Проаналізовано думки різних вчених щодо понять «представницька демократія», «пряма демократія» та «партисипативна демократія». Представницьку форму демократії визначено як форму здійснення влади в демократичному суспільстві, коли через конкретних осіб і виборні органи громадяни реалізовують своє гарантоване право брати участь у політичному житті суспільства. Пряму демократію охарактеризовано як особливу форму здійснення влади народу самим народом через певні інститути, а партисипативну демократію - як вищу форму прямої демократії, яка вкладає в себе більш широкий зміст, оскільки передбачає не лише пряме вирішення певних питань, а й вплив на сам процес прийняття значущих для громади рішень.

Узагальнено основні відмінності партисипативної демократії від представницької, серед яких насамперед те, що демократія участі передбачає участь особи в суспільних та політичних процесах безпосередньо, тобто член громади бере участь в управлінні громадою не через когось, а сам, особисто, через такі форми участі, як місцеві референдуми, місцеві вибори, загальні збори, місцеві ініціативи тощо. До того ж до відмінностей віднесено й те, що демократія участі передбачає ініціативу зі сторони членів громади.

Констатовано, що вдосконалення функціонування територіальних громад в Україні є актуальним питанням сучасності, а масштабніше впровадження в практику місцевого самоврядування форм партисипативної демократії сприятиме більш широкій та ефективній участі членів територіальних громад у вирішенні питань місцевого значення, а отже, слугуватиме розвитку місцевого самоврядування. Припустимим та корисним вбачається поєднання інструментів представницької та партисипативної демократії на місцевому рівні, однак без їхньої повної взаємозаміни.

Ключові слова: демократія, партисипативна демократія, представницька демократія, місцеве самоврядування, територіальна громада, реформа децентралізації влади.

\section{Nikitenko Liliia, Hrabar Oleksandra. Participatory and representative democracy in local government: the issue of correlation}

The article highlights the relationship between representative and participatory democracy in local self-government.

It is noted that the study of different types of democracy at the local level is relevant today in connection with the reform of decentralization of power, which is primarily aimed at the development of local self-government in Ukraine.

The opinions of various scholars on the concepts of "representative democracy", "direct democracy" and "participatory democracy" are analyzed. Representative form of democracy is defined as a form of exercising power in a democratic society, when through individuals and elected bodies, citizens exercise their guaranteed right to participate in the political life 
of society. Direct democracy is characterized as a special form of exercising power by the people through certain institutions, and participatory democracy - as a higher form of direct democracy, which has a broader meaning, as it provides not only a direct solution to certain issues, but also the impact on the adoption of significant for community solutions.

The main differences of participatory democracy from representative democracy are generalized, among which, first of all, that participatory democracy presupposes personal participation in social and political processes directly, ie a community member participates in community management not through someone, but personally through such forms of participation as local referendums, local elections, general meetings, local initiatives, etc. In addition, the differences include the fact that participatory democracy involves initiative on the part of community members.

It was stated that improving the functioning of territorial communities in Ukraine is a topical issue today, and large-scale introduction of forms of participatory democracy in local government will promote greater and more effective participation of members of territorial communities in local issues and, consequently, serve local government. A combination of the tools of representative and participatory democracy at the local level is considered acceptable and useful, but without their full interchangeability.

Key words: democracy, participatory democracy, representative democracy, local selfgovernment, territorial community, reform of decentralization of power.

Одним із сьогоднішніх пріоритетів державної політики України визначено розвиток місцевого самоврядування та реформування системи регіонального управління. Реалізація масштабної реформи місцевого самоврядування тягне за собою перерозподіл повноважень між органами державної влади та місцевого самоврядування, а також надання більших можливостей територіальним громадам як первинним суб'єктам місцевого самоврядування. Під наданням більших можливостей, серед іншого, розуміється розширення кола інструментів, за допомогою яких реалізується локальна демократія. У свідомості пересічних громадян, що складають територіальні громади, демократія майже завжди прирівнюється до народовладдя. Ця форма правління з точки зору механізму прояву народного суверенітету виступає як пряма і представницька демократія. Перший різновид передбачає безпосередню участь та волевиявлення територіальної громади з окремих питань її життєдіяльності. У цьому разі апарату влади відведена роль організатора волевиявлення і гаранта реалізації спільної волі громади, на основі якої влада приймає політичні рішення. Сьогодні набуває особливої популярності та поширення такий різновид прямої демократії, як партисипативна демократія, сутність якої насамперед полягає у залученні кожного у процес прийняття політичних рішень. Представницька ж демократія передбачає, що основні рішення приймають представницькі органи місцевого самовряду- вання, які обираються територіальною громадою. У зв'язку з цим актуалізується питання співвідношення представницької та партисипативної демократії в місцевому самоврядуванні. Розкриття цього питання дозволить визначити значення кожного з цих видів демократії для процесу проведення реформи місцевого самоврядування.

Питання локальної демократії висвітлювались раніше у наукових працях вітчиз-

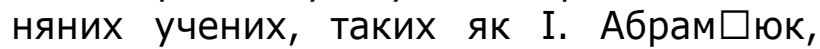
Г. Боднар, А. Васіна, Ю. Дзюбенко, І. Забокрицький, М. Коваленко, В. Ковальчук, К. Мануілова, В. Нестерович, А. Пехник, М. Ставнійчук, М. Требіна. Проте в умовах сьогодення доцільним вбачається дослідження різних видів демократії на місцевому рівні у контексті проведення реформи децентралізації влади.

Мета статті полягає у висвітленні співвідношення представницької та партисипативної демократії у місцевому самоврядуванні.

Поняттю «демократія» вже два з половиною тисячоліття. 3 розвитком і ускладненням політичного життя, появою різноманітних концепцій, що апелювали до демократії, ії розуміння істотно змінювалось та тлумачилося по-різному. Так, термін «демократія» вперше використав грецький історик Геродот, а його найвідоміше визначення належить 16-ому президенту США Аврааму Лінкольну: «Демократія - це правління народу, обране народом і для народу». 
Як сучасний юридичний та політичний термін «демократія» означає:

- особливу форму організації державної влади, де влада належить усім громадянам, які користуються рівними правами;

- структуру будь-якої організації, засновану на принципах рівноправності ії членів, періодичних виборів керівних органів та прийнятті ними рішень більшістю голосів;

- світогляд, що заснований на ідеалах свободи, рівності, поваги прав людини і меншин, народного суверенітету тощо;

- громадський рух з метою реалізації ідеалів демократії [1, с. 210].

Попри існування різних наукових підходів до розуміння демократії, в усіх цих значеннях як ознаки демократії виділено свободу та політичні права особистості, владу більшості при повазі прав меншості, рівність індивідів, пріоритет прав людини над правами держави. Сукупність цих політичних, моральних, правових цінностей складає сутність демократії.

Залежно від способу участі народу в здійсненні влади науковці вирізняють представницьку (репрезентативну) та безпосередню (пряму) форми демократії, які $\epsilon$ похідними від більш загального поняття «демократія» і тому характеризуються ознаками, властивими демократії загалом.

Представницька демократія - це комплексна категорія. В. Ковальчук та I. Забокрицький визначають представницьку демократію як «одну із форм вираження волі народу (народного суверенітету), яка передбачає оптимально ефективну процедуру прийняття владно-політичних рішень демократично обраними представницькими органам (що діють з урахуванням волі народу)» [2, с. 163].

«Представницька демократія - це демократія, у контексті якої громадяни не беруть безпосередньої участі в управлінні громадою і розв'язанні соціальних проблем, а натомість доручають це своїм представникам, уповноважуючи їх репрезентувати свої інтереси», - саме так розуміють представницьку демократію на місцевому рівні А. Васіна та Г. Боднар [3, с. 31].

М. Требіна характеризує представницьку демократію як «форму народовладдя, за якої право приймати рішення громада реалізує через обраних нею представників, які повинні відстоювати інтереси тих, хто їх обрав» [1, с. 553]. У своїх роботах вчена наголошує на тому, що представницька демократія неможлива без безпосередньої, яка $\epsilon$ єдиним способом формування представницьких демократичних органів [1, с. 556].

Безпосередня, тобто пряма, демократія $\epsilon$ прямим волевиявленням громадян у ході розробки, прийняття, впровадження державних рішень та у процесі здійснення народного контролю за цими рішеннями [4, с. 3]. На думку А. Пехник та Ю. Дзюбенко, пряма демократія на місцевому рівні припускає насамперед прийняття рішень більшістю при повазі прав меншості [5, с. 279].

Відомо, що одним з різновидів прямої демократії $\epsilon$ партисипативна, або, як її ще називають, демократія участі. Варто наголосити на тому, що не слід ототожнювати ці дві форми демократії, оскільки партисипативна демократія витікає з прямої, але не прирівнюється до неї.

Експерт проєкту ЄС «Підтримка політики регіонального розвитку в Україні» Ігор Абрам'юк демократію участі визначає таким чином: «Це такий вид демократії, який передбачає безпосередню участь членів територіальної громади в управлінні громадою (або громадян в управлінні державою), тобто у процесах підготовки, ухвалення управлінських рішень та контролю за їх реалізацією» [6, с. 4].

М. Ставнійчук розглядає партисипативну демократію як реальний інструмент для реалізації гарантованих Конституцією прав громадян та вважає, що ії різноманітні форми, починаючи 3 місцевих виборів і закінчуючи загальними зборами громадян за місцем їхнього проживання, місцевими ініціативами, громадськими слуханнями, органами самоорганізації населення, забезпечують волевиявлення громадян з метою здійснення суспільних функцій, які матимуть правові наслідки [7, c. 35].

На основі аналізу вищенаведених визначень можна зробити висновок, що представницька демократія - це така форма здійснення влади в демократичному суспільстві, коли через конкретних осіб і виборні органи громадяни реалізовують своє гарантоване Конституцією право 
брати участь у політичному житті суспільства. Пряма демократія - це особлива форма здійснення влади народу самим народом через певні інститути. А партисипативна демократія - це вища форма прямої демократії, яка вкладає в себе більш широкий зміст, оскільки передбачає не лише пряме вирішення певних питань, а й вплив на сам процес прийняття значущих для громади рішень. I пряма демократія, і демократія участі розглядаються як важливі елементи демократичного управління, роль яких змінюється протягом істоpiï $[8$, с. 67].

Дослідники різних поглядів, попри різницю у своїх аргументаціях, наполягають на збалансуванні домінуючої місцевої представницької демократії із партисипативною демократією. Варто наголосити, що загальна участь громадян спроможна повною мірою вплинути на покращення місцевого самоврядування, що може проявлятись у вирішенні особливо дратівливих та проблемних питань та у поліпшенні реагування на потреби різних груп населення. Участь у політичному житті дає громадянам можливість висловлювати свої побажання з важливих питань місцевого життя. Також широке залучення громадськості може допомогти місцевим органам влади бути більш чутливими до певних груп, враховувати підлокальні інтереси.

Відмінності між представницькою та партисипативною демократією у місцевому самоврядуванні можна пояснити на прикладі затвердження формальних рішень, а також прийняття відповідальності за рішення. Так, демократія участі залучає громадян до процесу прийняття рішень на місцевому рівні, але загалом це не призводить до остаточних офіційних рішень. Формальними рішеннями зазвичай не закінчуються консультації, громадські слухання, місцеві ініціативи, збори тощо. I навпаки, більшість традиційних форм прямої демократії (наприклад, референдуми, вибори) передбачають остаточне схвалення рішень. Однак пряме право на прийняття рішень належить саме представницькій демократії, яка $€$ головним конкурентом партисипативної. На місцевому рівні саме представницька демократія достатньо утвердилась та стабілізувалась.
Втім, сильна партисипативна демократія надає громадянам більше влади, можливість ефективніше контролювати діяльність місцевих інститутів представницької демократії, робить останні чутливими до потреб населення. Зважаючи на високий рівень участі громадян, що підтверджується статистичними даними, це може бути дуже впливовим механізмом у здійсненні місцевого самоврядування.

Враховуючи значущу роль демократії участі в сучасному місцевому самоврядуванні, варто вказати на потребу налагодження двох особливо важливих типів відносин: перший - це взаємозв'язок між інститутами місцевої представницької та партисипативної демократії; другий - це взаємозв'язок низки питань, пов'язаних $з$ інноваційними тенденціями в процесі надання муніципальних послуг, з місцевою партисипативною демократією.

Так, інститути місцевої представницької демократії можуть покращити умови участі різними способами. Розвиток представницької демократії, окрім залучення громадян до участі у виборах, має зосередитися на покращенні комунікації між посадовцями місцевого самоврядування та громадянами $[9$, с. 66]. Наступним кроком може бути додавання елементів демократії участі до представницької демократії. Місцева влада зазвичай використовує дуже стандартні форми участі, засновані на нерегулярних зустрічах 3 громадою та інших засобах комунікації і залучення. До участі в інститутах представницької демократії запрошуються представники окремих громад, а також кваліфіковані фахівці. Суть розширення представницької демократії полягає у формуванні різноманітних підлокальних інститутів, що $\epsilon$ вкрай привабливим і перспективним трендом останнього часу. Це розширення включає різні технології участі, різні форми виборних чи невиборних місцевих інституцій (ради / форуми / збори громад тощо) $[10$, с. 75].

Можна констатувати, що між партисипативною та представницькою демократією у місцевому самоврядуванні існує чітка межа. Представницька демократія - це здійснення місцевого самоврядування шляхом делегування громадянами своїх повноважень їхнім представникам 
(депутатам), які обираються до представницьких органів. Натомість партисипативну демократію можна розглядати як процес реального залучення широкого кола громадян до формування та ефективного функціонування місцевого самоврядування в їхніх інтересах.

Таким чином, порівнюючи представницьку демократію з партисипативною, можна чітко резюмувати, що остання дає більше можливостей для вираження волі та інтересів місцевого населення, забезпечує подолання політичного відчуження громадян, сприяє розвитку суспільної активності громади, а також забезпечує контроль за органами місцевого самоврядування та їх посадовими особами. Головною відмінною ознакою та перевагою партисипативної демократії $\epsilon$ те, що участь особи в суспільних процесах $\epsilon$ саме безпосередньою, тобто член громади бере участь в управлінні громадою не через когось, а сам, особисто, через вказані вище форми такої участі. До того ж до відмінностей партисипативної демократії від представницької можна віднести й те, що участь у вирішенні питань місцевого значення у цьому разі передбачає насамперед ініціативу зі сторони членів громади.

Вдосконалення функціонування територіальних громад в Україні $\epsilon$ актуальним питанням сучасності, а масштабніше впровадження в практику місцевого самоврядування форм партисипативної демократії сприятиме більш широкій та ефективній участі членів територіальних громад у вирішенні питань місцевого значення, а отже, слугуватиме розвитку місцевого самоврядування. Припустимим та корисним вбачається поєднання інструментів представницької та партисипативної демократії на місцевому рівні, однак без їхньої повної взаємозаміни.

\section{ЛIТЕРАТУРА:}

1. Політологічний енциклопедичний словник / Л.М. Герасіна, В.Л. Погрібна, І.О. Поліщук та ін.; за наук. ред. М.П. Требіна. Харків : Право, 2015. 816 с.

2. Ковальчук В.Б., Забокрицький I.I. Представницька демократія: поняття, ознаки, критерії. Вісник Національного університету «Львівська політехніка». Серія: Юридичні науки. 2015. № 824. С. 159-163.

3. Боднар Г. Місцеві вибори як форма представницької демократії. Актуальні проблеми вітчизняної економіки, підприємництва та управління на сучасному етапі (частина 2): матеріали доп. V Ювіл. наук.-практ. конф. студ. та молодих вчен. з міжнар. участю (Тернопіль, 12 листопада 2020 р.). Тернопіль : ЗУНУ. 2020. С. 31-34.

4. Мануілова К.В. Пряма демократія як складовий чинник децентралізованої публічної влади. Державне управління: удосконалення та розвиток. 2015. №11. С. 1-6.

5. Пехник А.В., Дзюбенко Ю.М. Безпосередня демократія як форма реалізації народовладдя в Україні (місцевий рівень). Актуальні проблеми політики. 2018. Вип. 61. С. 275-285.

6. Абрам'юк I. Демократія участі: механізми громадської участі на місцевому, регіональному та національному рівнях. Всеукраїнська мережа фахівців та практиків з регіонального і місцевого розвитку. Матеріали до курсу. № 7. 2014. С. 1-50.

7. Ставнійчук М. Демократія участі в Україні: актуальний конституційно-правовий аспект. Юридичний вісник. 2016. № 2. С. 35-45.

8. Нестерович В.Ф. Конституційно-правова модернізація органів державної влади у рамках утвердження демократії участі в Україні. Науковий вісник Львівського державного університету внутрішніх справ. Серія юридична. 2016. № 1. С. 67-76.

9. Коваленко М.Г. Напрями удосконалення конституційно-правових засад партисипативної демократії на місцевому рівні в Україні. Актуальні проблеми державного будівництва та місцевого самоврядування в контексті конституційної модернізації: зб. наук. ст. за матеріалами наук.-практ. семінару (Харків, 14 жовтня 2016 р.). 2016. С. 62-70.

10. Нестерович В.Ф. Принципи відкритості та прозорості у діяльності органів державної влади як важлива передумова для утвердження демократії участі. Філософські та методологічні проблеми права. 2016. № 2. С. 67-76. 